\title{
・特集 続・ポリマー/フィラー間の相互作用と加工性・物性
}

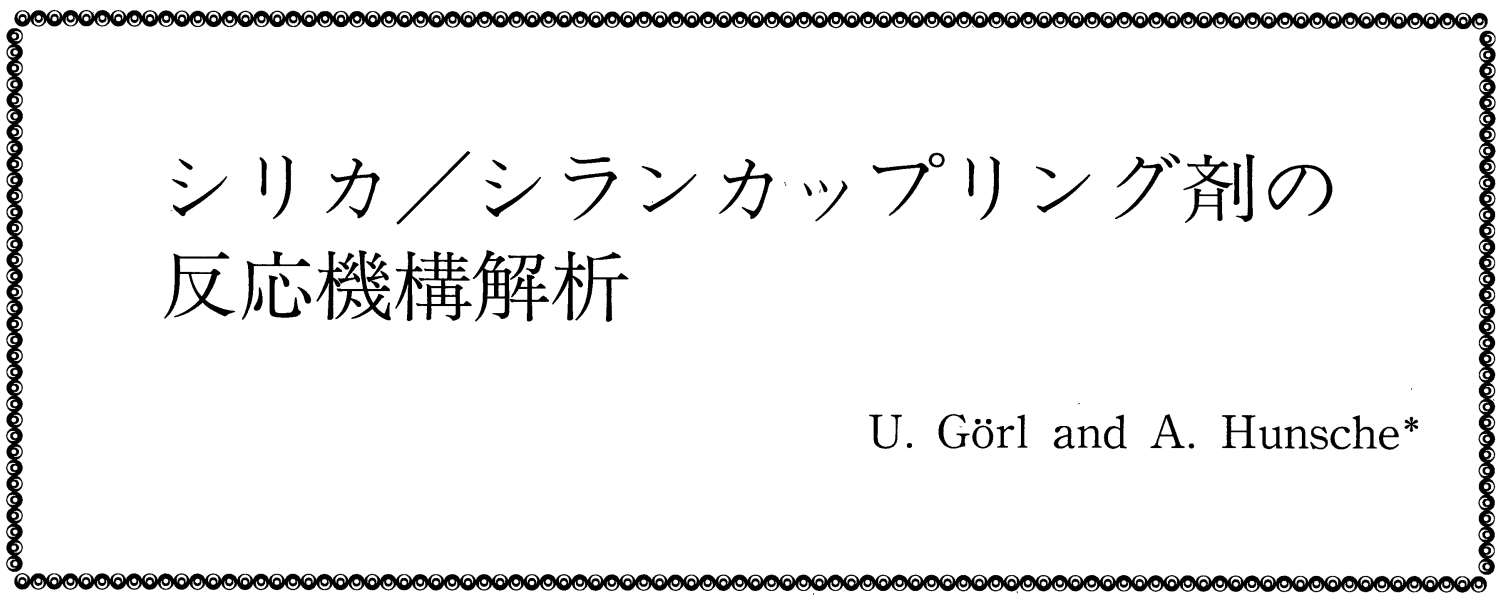

最近タイヤ用トレッドゴムに適用されるように なってきたシリカ配合の夕イヤ性能の特徵はカー ボンブラック配合に比べ耐摩耗性を低下させるこ となく転がり抵抗と湿潤路面での摩擦特性 (ウ工 ット性能）を改善できることにある。これらの性 能を得るためのシリカ配合はシリカとジランカッ プリング剂 (bis ( 3 - triethoxysilylpropyl) tetrasulfane $=$ TESPT)の併用が必要である。一 般にこのシランカップリング剂は混練りの中にシ リカ表面のシラノール基と反応し，加硫中にポリ マーと反応するといわれている.

ここでは，このシリカとシランカップリング剤 との反応機構や，反応速度に及ぼすシランカップ リング剂の量, $\mathrm{pH}$ ，水分の影響を調べた。結合

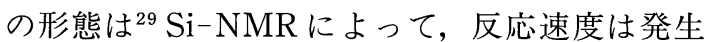
するエ夕ノールを定量分析することによって解析 した。その結果，シリカとシランカップリング剂 の反応はシリカ表面のシラノール基とシランカッ プリング剂の 1 つのメトキシ基が反応する 1 次反 応と, シリカ表面で結合したシランカップリング 剂同士の縮合する 2 次反応が起こると考えられ る。それぞれの反応速度の解析から 1 次反応は速 く，2 次反応は遅いことがわかった。 そして，こ
れらの結合形態は 1 次反応でシランカップリング 剂のエトキシ基が反応してシラノール結合を形成 し, 次の 2 次反応で近接するシランカップリング 剂同士が反応しシラノール結合を形成することに よりシリカ表面をシランカップリング剤が手をつ ないで覆うようなモデル(horizontal reaction model) が NMR 解析やシラノール基の結合角等 の検討より，現実的ではないかと考えた，次にこ れらの反応に関するシランカップリング剂の量 $(5,8,12 \mathrm{pbw}), \mathrm{pH}(\mathrm{pH} 5.0,6.2,9.0)$ ，水 分量 $(2.5,5.5,8.0 \%)$ の影響について実験した ところ次のような結果が得られた。シランカップ リング剤の量は少ないほうがどちらの反応速度と も速く，またシランカップリング剂 1 モル当たり に発生するエ夕ノールモル比も高くなることがわ かった．次に $\mathrm{pH}$ の影響はどちらの反応も中性 $(\mathrm{pH}=6.2)$ のときが一番遅く, 酸性 $(\mathrm{pH}=5.0)$ や アルカリ性 $(\mathrm{pH}=9.0)$ になると速くなることがわ かった。水分量の影響は 1 次反応速度は水分量が $2.5 \%$ のきが遅く，5.5 と $8.0 \%$ ではほぼ同じ であるが， 2 次反応は水分量が多くなるにつれて 速くなることがわかった。 


\title{
ADVANCED INVESTIGATIONS INTO THE SILICA/SILANE REACTION SYSTEM ${ }^{\dagger}$
}

\author{
U. Görl and A. Hunsche \\ Degussa AG, Business Area Rubber Chemicals and Pigments, Applied Technology, \\ Kalscheurener Str. 11, D-50354 Hürth, Federal Republic of Germany
}

\begin{abstract}
Silica in combination with bifunctional organosilanes (e.g. [Bis(3-triethoxysilylpropyl) tetrasulfane $]=$ TESPT) have recently become more important in the tire application. Their use in tire treads as a replacement of carbon black leads to an improvement in rolling resistance and wet traction without loss in abrasion resistance. The requirements for the attainment of this combination of properties are that the triethoxysilyl groups of TESPT react with the silanol groups on the silica surface during compounding, and the polymer active groups react with the polymer during cure.

The reaction of precipitated silica with this silane was investigated. The influence of various parameters (silane concentration, $\mathrm{pH}$, moisture content) on the reaction type, degree of reaction and the reaction kinetics were considered. The results of the investigation obtained using ${ }^{29} \mathrm{Si}-\mathrm{CP} / \mathrm{MAS}$ solid state NMR spectroscopy agree well with a horizontal reaction model in which a single siloxane bond is first formed with the silica surface (primary reaction), either directly or after (partial) hydrolysis of the silane. After having given off further ethanol, it is followed by condensation reactions between silanol groups of silane molecules which are already bound to the silica surface (secondary reaction).

The data of the kinetic studies show a clear difference between the quick primary reaction and the slow secondary reaction. The energy of activation according to Arrhenius was determined for both reactions and was found to be much lower for the secondary reaction. Both reactions become quicker in the acidic and alkaline ranges respectively.

The primary reaction accelerates up to a particular $\mathrm{H}_{2} \mathrm{O}$ content after which the rate remains constant. The secondary reaction on the other hand keeps on accelerating with rising $\mathrm{H}_{2} \mathrm{O}$ content.

Modification with different silane concentrations showed a noticeably higher rate constant at low concentrations and a greater amount of ethanol formed per mol of silane.
\end{abstract}

\section{INTRODUCTION}

The use of silicas in combination with bifunctional organosilanes, particularly bis (triethoxysilylpropyl) tetrasulfane(TESPT), is becoming more and more important in rubber applications ${ }^{1}$. In tires, more precisely in passenger tread compounds, the two product groups are increasingly being used to reduce rolling resistance ${ }^{2-3)}$. Two factors are responsible for the properties achieved with these two product groups. On the one hand, the triethoxysilyl group of the TESPT reacts with the silanol groups of the silica during compounding with loss of ethanol. On the other hand, the rubber -reactive group of the silane (e.g. tetrasulfane) has a strong tendency to form rubber-to-filler bonds during curing of the rubber compound ${ }^{4}$.

$\uparrow:$ Parts of this paper have been published by $\mathrm{A}$. Hunsche, U. Görl, A. Müller, M. Knaack, Th. Göbel, Kautschuk Gummi Kunststoffe, 50, 881889 (1997) 
In order to obtain optimum in-rubber properties, it is necessary to ensure that both reactions, but particularly that between silica and silane, take place under specific, closelycontrolled conditions ${ }^{4-5}$. This presentation describes investigations which were carried out using state-of-the-art test mothods on the one side to determine the reaction mechanism and on the other the kinetic aspects of the above mentioned reaction under the influence of substance-specific parameters and reaction conditions.

\section{APPROACH}

The first section deals with the mechanism of the reaction between silica and TESPT. For this purpose, silicas and TESPT were reacted with each other outside of the rubber compounds and tested by ${ }^{29} \mathrm{Si}-\mathrm{CP} / \mathrm{MAS}$ solid state NMR spectroscopy.

First, qualitative and quantitative determinations of the silanol groups of the silica filler are carried out. The silica is then tested to determine the changes that it undergoes when it is reacted with the silane. These changes are evaluated as a function of fillerparameters $(\mathrm{pH}$, moisture) and the silane concentration.

On the basis of these results, it should then be possible to develop a model that describes the reaction between the silica-filler and TESPT.

Further investigations were carried out in a suitable organic solvent to determine the kinetic aspects of the reaction in dependence on the filler and silane parameters and the reaction temperature.

\section{EXPERIMENTAL REACTANTS}

The analytical data of the slica chosen for the investigations are shown in Table 1. The silane used for the tests was TESPT.

In order to determine the kind of reactions taking place and the type of bonds formed the
Table 1 Analytical data of the silica used

\begin{tabular}{l|c|c}
\hline $\mathrm{N}_{2}$ surface area $\left[\mathrm{m}^{2} / \mathrm{g}\right]$ & ISO 5794/1D & 170 \\
CTAB surface area $\left[\mathrm{m}^{2} / \mathrm{g}\right]$ & - & 165 \\
DBP number[ml/100g] & ASTM D 1208 & 200 \\
$\mathrm{pH}$ & ISO 787/9 & 6.2 \\
Moisture[weight\%] & ISO 787/2 & 5.5 \\
\hline
\end{tabular}

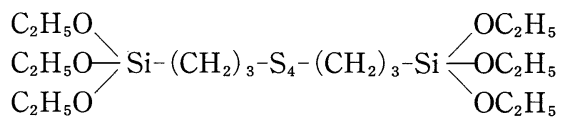
TESPT

silica was reacted with the silane for $6 \mathrm{~min}$ at a temperature of approx. $150^{\circ} \mathrm{C}$ in a highperformance mixer and analyzed as described below. The amount of TESPT was varied between 5 , 8 , and 12 parts by weight (pbw).

In order to determine the influence of the $\mathrm{pH}$ value on the silica/silane reaction, the $\mathrm{pH}$ of the silica was adjusted from orginally 6.2 to 9.0 and 5 resp. by controlled addition of $2 \mathrm{~N}$ $\mathrm{NaOH}$ and $2 \mathrm{~N} \mathrm{H}_{2} \mathrm{SO}_{4}$ resp. followed by a homogenization in a high-performance mixer. The reaction product was heated at $105^{\circ} \mathrm{C}$ in order to obtain a residual moisture content of 5 . $5 \%$. It was then reacted with 8 pbw of TESPT as described above.

In order to determine the influence of the moisture content of the filler on the silica/ silane reaction, the original silica was adjusted to a moisture content of approx. 2.5 weight\% by heating to $105^{\circ} \mathrm{C}$. Another variation in moisture content was obtained by spraying the original silica with $\mathrm{H}_{2} \mathrm{O}$ up to a level of $8.0 \%$. All the silica samples were then reacted with 8 pbw of TESPT as described above.

To determine the kinetic reaction parameters, both ingredients were brought to reaction in an in-situ process. During the reaction the loss of ethanol was measured as a function of reaction time. This is in contrast to the spectroscopic investigations which are performed on premodified products. 
Table 2 Equipment parameters for $\mathrm{CP} / \mathrm{MAS}$ NMR measurements

\begin{tabular}{l|l}
\hline & $\begin{array}{c}{ }^{29} \mathrm{Si}-\mathrm{CP} / \mathrm{MAS} \text { solid state } \\
\text { NMR spectroscopy }\end{array}$ \\
\hline Spectrometer : & $\begin{array}{l}\text { Bruker AM 250 } \\
\text { solid state conversion for 7 } \\
\text { mm rotors }\end{array}$ \\
\hline $\begin{array}{l}\text { Test } \\
\text { frequency : }\end{array}$ & $49.7 \mathrm{MHz}$ \\
\hline $\begin{array}{l}\text { Spinner } \\
\text { frequency : }\end{array}$ & approx. $4 \mathrm{kHz}$ \\
\hline $\begin{array}{l}\text { Relaxation } \\
\text { delay : }\end{array}$ & $5 \mathrm{~s}$ \\
\hline $90^{\circ}$ pulse $\mathrm{H}-1:$ & $7.6 \mu \mathrm{s}$ \\
\hline Contact time : & $1 \mathrm{~ms}$ \\
\hline
\end{tabular}

\section{METHODS OF TESTING AND ANALYSIS}

The silica/silane reaction products were subjected to ${ }^{29} \mathrm{Si}$-solid solid state NMR spectroscopy to determine the reaction mechanism between silica and silane. The equipment and test parameters are shown in Table 2. In order to ensure comparability of the peak intensities in the NMR spectra, all CP tests were run with constant contact times.

The evaluation of the peak intensities obtained in the spectra will be described in detail in the respective chapters.

The investigations into the kinetics were started by weighing the silica into glass ampules of ca. $25 \mathrm{ml}$ volume and then mixing with a defined volume of $n$-Decane. A defined volume of a solution of the silane in $n$-Decane was added to this mixture and the silica and silane were brought to reaction at elevated temperature. At fixed intervals samples of the reaction products in an ampule were submerged in an ice bath in order to stop the reaction. The amount of ethanol evolved during the reaction time was quantified using HPLC.

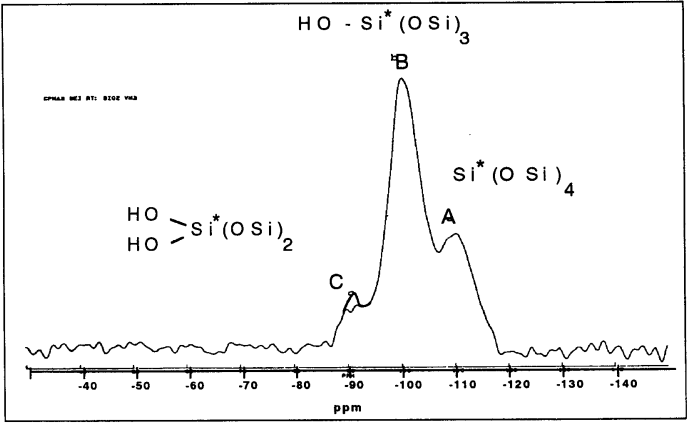

Fig. $1{ }^{29} \mathrm{Si}-\mathrm{CP} / \mathrm{MAS}$ spectrum of a precipitated silica

Table 3 Relative peak intensities in the ${ }^{29} \mathrm{Si}-\mathrm{CP} / \mathrm{MAS}$ spectrum of a silica

\begin{tabular}{c|c|c}
\hline $\mathrm{A}$ & $\mathrm{B}$ & $\mathrm{C}$ \\
\hline 28 & 100 & 15 \\
\hline
\end{tabular}

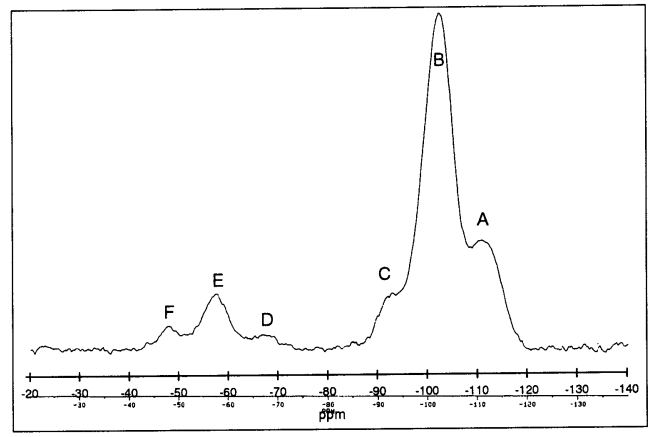

Fig. $2{ }^{29} \mathrm{Si}-\mathrm{CP} / \mathrm{MAS}$ spectrum of a silica silanized with TESPT

Table 4 Relative peak intensities (A, B, C) in a ${ }^{29} \mathrm{Si}-\mathrm{CP} / \mathrm{MAS}$ spectra of TESPT-modified silicas with different silane concentrations

\begin{tabular}{c|c|c|c}
\hline TESPT $(\mathrm{pbw})$ & $\mathrm{A}$ & $\mathrm{B}$ & $\mathrm{C}$ \\
\hline 0 & 28 & 100 & 15 \\
\hline 5 & 38 & 100 & 13 \\
\hline 8 & 40 & 100 & 13 \\
\hline 12 & 41 & 100 & 13 \\
\hline
\end{tabular}




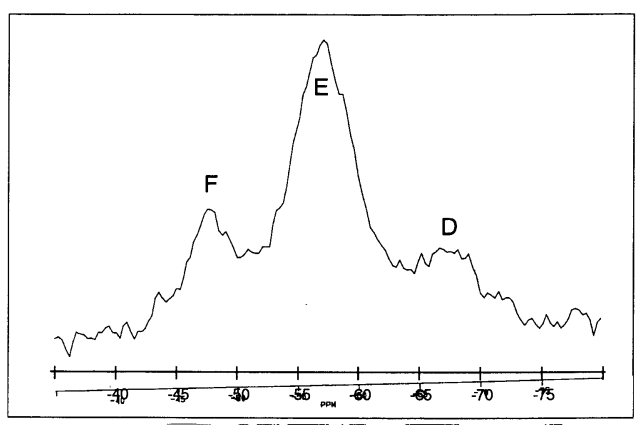

Fig. 3 Section (silane section) from the ${ }^{29} \mathrm{Si}-\mathrm{CP} / \mathrm{MAS}$ spectrum of a TESPT-modified silica

Table 5 Attribution of the silane peaks $\left(\mathrm{R}=\mathrm{C}_{2} \mathrm{H}_{5}\right.$ or $\mathrm{H})$ in the ${ }^{29} \mathrm{Si}-\mathrm{CP} / \mathrm{MAS}$ spectrum of TESPT. modified silica

\begin{tabular}{c|lc}
\hline Peak & \multicolumn{2}{|c}{ Si Atnm } \\
\hline D & $(-\mathrm{O})_{3}$ & $\mathrm{Si}\left(\mathrm{CH}_{2}\right)_{3} \mathrm{~S}^{-}$ \\
E & $(-\mathrm{O})_{2}(\mathrm{RO})$ & $\mathrm{Si}\left(\mathrm{CH}_{2}\right)_{3} \mathrm{~S}^{-}$ \\
F & $(-\mathrm{O})(\mathrm{RO})_{2}$ & $\mathrm{Si}\left(\mathrm{CH}_{2}\right)_{3} \mathrm{~S}^{-}$ \\
\hline
\end{tabular}

\section{REACTION MECHANISM AND REACTION MODEL DETERMINATION OF THE DIFFERENT TYPES OF SILANOL GROUPS ON UNTREATED SILICA}

Figure 1 shows the ${ }^{29} \mathrm{Si}-\mathrm{CP} / \mathrm{MAS}$ solid state NMR spectrum of an untreated silica according to Table 1 . Three peaks are observed which can be attributed to silicon atoms with (A) no $\mathrm{OH}$ groups, (B) one $\mathrm{OH}$ group, and (C) two (geminal) OH groups, respectively' ${ }^{6}$.

The peak intensities (A), (B), and (C) were determined by deconvolution of the spectrum and are given in Table 3. The intensity of the highest peak (B) was defined as 100 .

\section{INVESTIGATION INTO SILANE-MODIFIED SILICAS}

Influence of the silane concentration.The silica was reacted with three different amounts $(5,8,12 \mathrm{pbw})$ of TESPT, and the reaction products were evaluated by ${ }^{29} \mathrm{Si}-\mathrm{CP} /$ MAS solid state NMR spectroscopy. Figure 2
Table 6 Relative peak intensities of TESPT-modified silicas as a function of the silane concentration

\begin{tabular}{c|c|c|c}
\hline $\begin{array}{c}\text { TESPT } \\
\text { concentration } \\
(\mathrm{pbw})\end{array}$ & $\mathrm{D}$ & $\mathrm{E}$ & $\mathrm{F}$ \\
\hline 5 & 11 & 52 & 37 \\
\hline $8^{\mathrm{a}}$ & 13 & 55 & 32 \\
\hline 12 & 14 & 57 & 29 \\
\hline
\end{tabular}

${ }^{\mathrm{a}}$ corresponds to the spectrum in Fig.3

shows the spectrum of the product obtained by reacting the silica with 8 pbw of TESPT, and Table 4 the change of the relative intensities of the peaks $(\mathrm{A})$ and $(\mathrm{C})$ in comparison to peak (B) of the silica, with varying TESPT concentration $^{7)}$.

The results presented in the above table show that, as a result of the reaction between silica and TESPT, the strength of the network $\mathrm{SiO}_{4}$ groups (A) increases in relation to the silanol functions (B) and (C). Furthermore, the increased TESPT concentration is also reflected, if only slightly, in the increased intensity of peak $(\mathrm{A})^{8}$. In other words, the reaction with TESPT leads to a reduction in the density of silanol groups on the silica surface.

In the range between -70 and $-40 \mathrm{ppm}$, the silicon NMR spectrum detects groups of peaks which can be attributed to the silicon atoms of the organosilane. Figure 3 shows the respective peak section for the reaction product containing $8 \mathrm{pbw}$ of TESPT.

Qualitatively, the peaks can be attributed as follows (Table 5) ${ }^{9}$ :

Peak (D) identifies a silicon atom where all of the ethoxy groups of the silane have reacted to form siloxane bonds. Peak (E) can be attributed to a silicon atom where the triethoxysilyl group of the silane has reacted with formation of two siloxane bonds. The chemical shift of peak (F) points towards silicon atoms where the triethoxysilyl group of the silane has reacted with formation of only one siloxane 


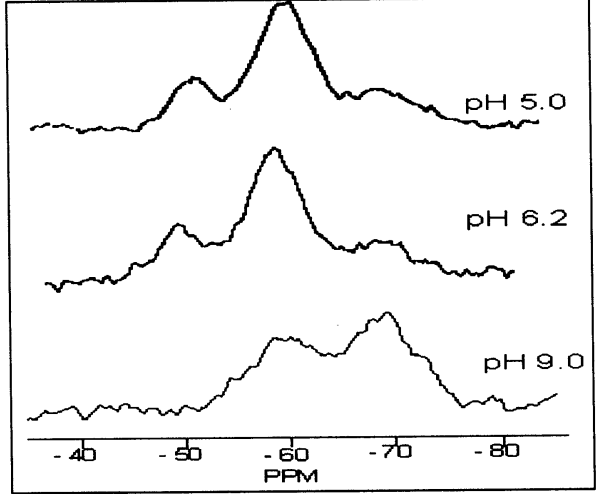

Fig. $4{ }^{29} \mathrm{Si}-\mathrm{NMR}$ spectra of TESPT-modified silicas with different $\mathrm{pH}$ values

Table 7 Relative peak intensities (D, E, F) in the ${ }^{29} \mathrm{Si}$-CP/MAS spectra of TESPT-modified silicas having different $\mathrm{pH}$ values

\begin{tabular}{l|c|c|c}
\hline & D & E & F \\
\hline pH5 & 20 & 62 & 18 \\
\hline pH6.2 & 13 & 55 & 32 \\
\hline pH9.0 & 66 & 34 & - \\
\hline
\end{tabular}

bond. In the case of peaks (E) and (F), it is furthermore conceivable that these silicon atoms had given off ethanol in a hydrolysis reaction with formation of hydroxyl groups, but that the ensuing condensation reaction with the silanol groups of the silica or condensation reaction with other TESPT molecules has taken place only partially. This would have led to different chemical environments of the silicon atoms which should be reflected in separate peaks which could be detected by different chemical shifts. However, the ${ }^{29} \mathrm{Si}-\mathrm{CP} / \mathrm{MAS}$ solid state NMR spectrum is usually unable to resolve these groups of peaks ${ }^{9}$.

Information concerning the respective degrees of reaction can be obtained by evaluating the peak intensities (D), (E), and (F). At constant relaxation times $T_{i s}$ and $T_{1 s}$, it is; possible to compare the respective peak intensities.

For the silica/TESPT reaction products,

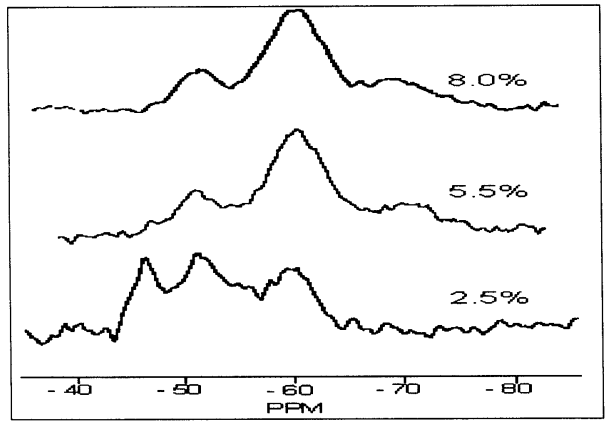

Fig. $5{ }^{29} \mathrm{Si}-\mathrm{CP} / \mathrm{MAS}$ spectra of TESPT-modified silicas with different moisture contents (siliane section)

Table 8 Relative peak intensities (D, E, F, G) of TESPT-modified silicas with different moisture contents

\begin{tabular}{c|c|c|c|c}
\hline $\begin{array}{c}\text { Moisture } \\
\text { content }\end{array}$ & $\mathrm{D}$ & $\mathrm{E}$ & $\mathrm{F}$ & $\mathrm{G}$ \\
\hline $8 \%$ & 17 & 63 & 20 & - \\
\hline $5.5 \%$ & 13 & 55 & 32 & - \\
\hline $2.5 \%$ & - & 34 & 46 & 20 \\
\hline
\end{tabular}

integration as a function of the above silane concentration yielded the following ratios for peaks (D), (E) and (F) (Table 6):

It can be assumed that at least one ethoxy group of each silicon atom has reacted under release of ethanol and formation of a siloxane bond. The existence of peaks (E) and (D) furthermore show that silicon atoms can also be detected where two or three ethoxy groups have reacted with formation of siloxane bonds. Peak (E), i.e. silicon atoms with two silloxane bonds, clearly accounts for the greatest share, whereas under the given reaction conditions there is only a relatively small concentration of silicon atoms (D) where all ethoxy groups have reacted and formed siloxane bonds.

Influence of the $p H$ of the silica on the modification reaction. - Silicas with different $\mathrm{pH}$ values $(5.0 ; 6.2$ and 9 , respectively) were reacted with equal amounts of TESPT $(8 \mathrm{pbw})$ and tested by means of the above method. Figure 4 shows a comparison of the silicon- 
NMR spectra for the silane section, Table 7 their quantitative evaluation.

The quantitative evaluation of peaks (D), $(\mathrm{E})$, and $(\mathrm{F})$ related to $\mathrm{pH}$ clearly shows a decrease in intensity of peak $(F)$ for the acidic and especially for the alkaline sitica. This signifies the in both cases a greater number of siloxane bonds could be formed at the silica surface or by partial oligomerization of the silane. It is assumed that this phenomenon is caused by the fact that an alkaline and an acid $\mathrm{pH}$ acts as a catalyst in the hydrolysis reaction of the silane with formation of ethanol and that it thus enhances the reaction both with the filler surface and in the ensuing inter-bonding of adjacent Si 69 molecules.

Influence of the moisture content of the filler on the silanization reaction. - Silicas with different $\mathrm{H}_{2} \mathrm{O}$ contents $(2.5 \%, 5.5 \%$ and $8 \%$ ) were reacted with equal amounts of TESPT (8pbw). These TESPT modified silicas were then investigated using ${ }^{29} \mathrm{Si}-\mathrm{NMR}$ spectroscopy. Figure 5 shows the silane part of the silicon-NMR-Spectra of the three products and Table 8 an evaluation regarding the intensity of the signals. Therefore it is quite clear that the efficiency of the reaction rises with rising $\mathrm{H}_{2} \mathrm{O}$ content. An additional signal $\mathrm{G}$ to which a silicon atom of TESPT can be associated and which has not formed a bond with the silica surface first appeared at $2.5 \%$ moisture. The results show quite clearly that the moisture in the silica catalyzes the reaction between filler and TESPT. A possible explanation of this effect could be an accelerated hydrolysis of the silane.

\section{REACTION MODEL SILICA/TESPT}

Hydrolysis of the triethoxysilyl group. By means of the ${ }^{29} \mathrm{Si}-\mathrm{CP} / \mathrm{MAS}$ solid state NMR spectra, we were able to show that the above reaction takes place between the silanol groups of the silica and the triethoxysilyl groups of the silane, or among the triethoxysilyl groups themselves, with formation of siloxane bonds. The

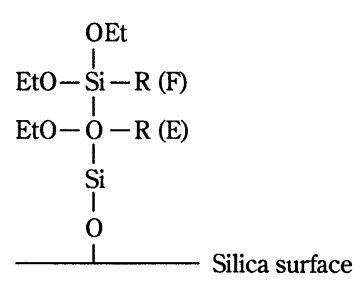

Model 1

occurrence of the first reaction is demonstrated by the increased intensity of peak (A) for silicon atoms without $\mathrm{OH}$ groups in relation to the sum of mono- and di-silanol groups ( $\mathrm{B}$ and $\mathrm{C}$, respectively). Significant differences in reactivity of the different types of silanol groups, i. e. a selectivity regarding the triethoxysilyl group, were not observed.

The question whether the triethoxysilyl function reacts directly with the silanol groups of the silica or after hydrolysis (with formation of alcohol) followed by a condensation reaction, is answered in the literature ${ }^{9)}$ with the single-step reaction. However, the fact that the silanization reaction with a pre-dried filler leads to a noticeably lower yield in siloxane bonds suggests that an initial hydrolysis as a reaction cannot be ruled out.

The water required for an intermediate hydrolysis step is adsorbed onto the silica surface and can easily be detected by means of IR spectroscopy.

The following factors furthermore support this reaction mechanism:

- Increases in the moisture content of the silica lead to a rise in inter-bonding.

- Increases in the $\mathrm{pH}$ catalyze the hydrolysis of the silane and hence its secondary reaction.

Condensation reactions of the organosilane. - The organosilane peaks in the ${ }^{29} \mathrm{Si}-\mathrm{CP} /$ MAS solid state NMR spectrum between -70 and $-40 \mathrm{ppm}$ representing one, two, and three siloxane bonds, respectively, can be explained by assuming a condensation reaction of individual silane molecules with silanol groups of the silica surface or, after hydrolysis, with other 

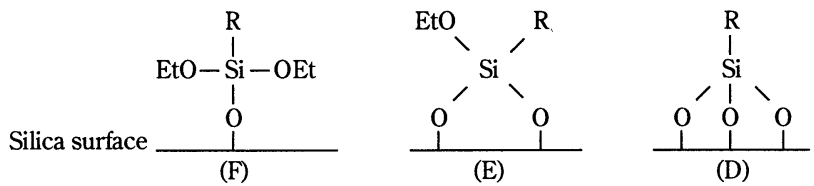

Model 2

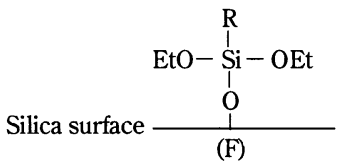

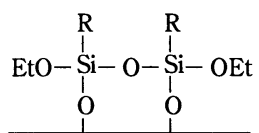

(E)

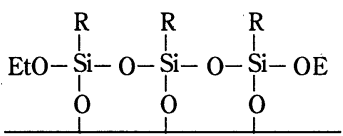

(E) (D) (E)

Model 3

neighbouring silane molecules. Three different models can be discussed:

Model 1 (vertical model) assumes a reaction of the silane with the silica surface and furthermore admits the possibility of funther silane molecules condensing onto a silane molecule which is already bound to the silica surface. This would explain peaks (E) and (F), but not peak (D) which was clearly detected by ${ }^{29} \mathrm{Si}-\mathrm{CP} / \mathrm{MAS}$ solid state NMR spectroscopy.

Similar investigations described in the literature ${ }^{9)}$ with silicas modified with chloro silanes, favor a horizontal model. Two variants can be discussed here :

In Model 2, the silane forms all of the siloxane bonds by reacting with the silanol groups of the silica. This would explain all
NMR signals observed. However, the difficulty with this assumption lies in the fact that the geometry of two and particularly three siloxane bonds with the silica surface is difficult to realize.

Two packing models for silanol groups on the silica surface discussed in the literature ${ }^{10-11)}$, of which one assumes a regular hexagonal and the other a square planar form of packing, both fix the distance between the silanol groups in their respective geometries at $5 \AA$. Even by assuming the maximum value for the $\mathrm{Si}-\mathrm{O}$ distance of $1.72 \AA$, it is evident that these packing models are unrealistic. If one assumes a maximum angle of the $\mathrm{Si}-\mathrm{O}-\mathrm{Si}$ bond of $122^{\circ 11}$, the bond would have to cover a distance of $2.9 \AA$ in order to bridge the gap

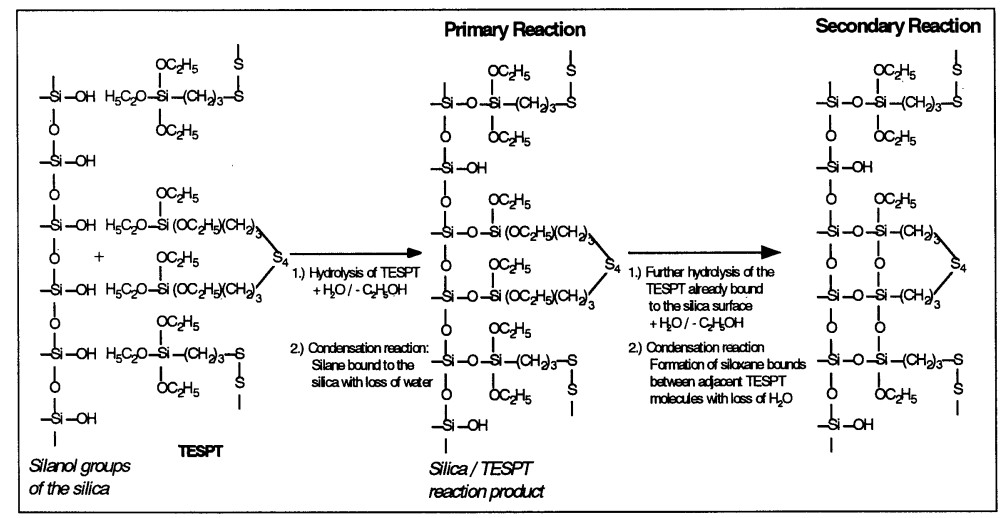

Fig. 6 Reaction mechanism of the silanization reaction 


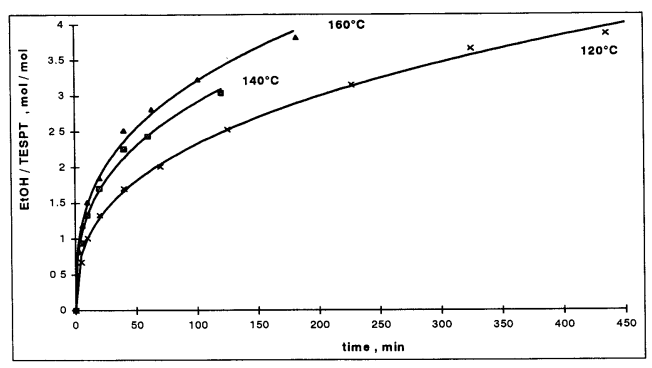

Fig. 7 Silica/TESPT reaction at different temperatures

between two silanol groups $(5 \AA)$.

The structures according to Model III, on the other hand, with single siloxane bonds on the silica surface can easily be realized with some slight adjustment within the framework of common bond lengths and bond angles. The structures in Model 3 are based on the as sumption that first a simple bond with the silica surface is formed(primary reaction). This primary reaction may be followed, after a hydrolysis reaction, by condensation reactions between pairs of neighbouring silane molecules already bound to the silica surface (secondary reaction).

Figure 6 presents the assumed course of the silica/TESPT reaction in the form of a general reaction model. Nevertheless, this is by no means the only conceivable possibility. Side reactions in one form or another certainly have to be taken into account as well.

\section{KINETICS OF THE TESPT/SILICA REACTION \\ INFLUENCE OF THE REACTION TEM- PERATURE}

8 pbw per weight TESPT were reacted with 100 pbw silica at temperatures of 120,140 and $160^{\circ} \mathrm{C}$. The kinetics were traced by the amount of ethanol formed. Figure 7 shows the corresponding curves.

It is noteworthy that the ethanol concentration rises sharply until $2 \mathrm{~mol}$ (pro mol TESPT) is reached(primary reaction) and thereafter rises slowly at a constant rate. These results

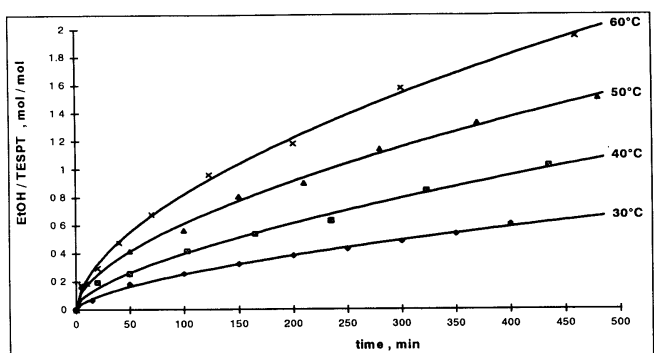

Fig. 8 Separation of the primary reaction by lowering the reaction temperature

suggest that secondary reactions are proceeding. Therefore an attempt was made to define the primary reaction by reducing the temperature. It is possible to develop a mathematical relationship(equation 3) for the technically interesting range of both the primary and the secondary reaction from the kinetic data for the primary reaction, which was obtained by quantifying the ethyl alcohol evoled between 30 and $60^{\circ} \mathrm{C}$.

Primary Reaction. - The effect of temperature influence on the reaction will be more fully described. It can be analogously related to other parameters which influence the reaction such as silane concentration, $\mathrm{pH}$ and water content of the filler. Figure 8 shows the evolution of ethanol at temperatures between 30 and $60^{\circ} \mathrm{C}$.

It is seen that $1 \mathrm{~mol}$ TESPT reacts with the formation of 2 mols of ethanol when the reduction of TESPT is balanced against the evolution of ethanol. This primary reaction

$$
\mathrm{TESPT} \rightarrow \mathrm{Z} 1 \rightarrow 2 \mathrm{EtOH}
$$

$\mathrm{Z1}=$ primary reaction product

is described by the following first order equation.

$-\frac{\mathrm{d}[\mathrm{TESPT}]}{\mathrm{dt}}=\mathrm{k}_{\mathrm{a}}[\mathrm{TESPT}]_{0}=\frac{1}{2} \frac{\mathrm{d}[\mathrm{EtOH}]}{\mathrm{dt}}$

[TESPT], $[\mathrm{EtOH}]=$ concentration of

TESPT and ethanol resp. in $\mathrm{mol} / \mathrm{kg}$ $[\text { TESPT }]_{0}=$ initial TESPT concentration $\mathrm{t}=$ time in minutes

$\mathrm{k}_{\mathrm{a}}=$ rate constant in minute $\mathrm{e}^{-1}$ 


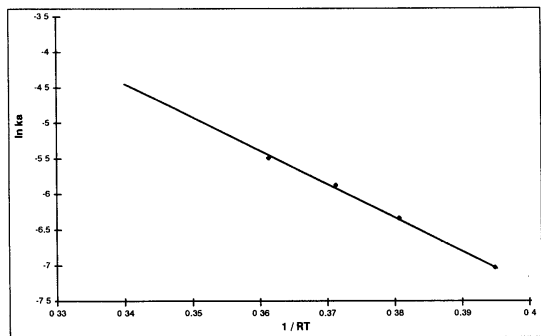

Fig. 9 Determination of the energy of activation for the primary reaction

Table 9 Rate constants for the above mentioned temperatures

\begin{tabular}{c|c|c|c|c}
\hline Temp. $\left({ }^{\circ} \mathrm{C}\right)$ & 30 & 40 & 50 & 60 \\
\hline $\mathrm{K}_{\mathrm{a}}\left(\mathrm{min}^{-1}\right)$ & 0.0008 & 0.0015 & 0.0027 & 0.0043 \\
\hline
\end{tabular}

Based on the assumption that $1 \mathrm{~mol}$ TESPT reacts to form 2 mols ethanol the concentration of TESPT at any time is determined from the amount of ethanol evolved. This amount is determined experimentally. The rate constant $\mathrm{k}_{\mathrm{a}}$ is determined in the usual manner by plotting [TESPT]/[TESPT]。 against time, $\mathrm{t}$ ( Table 9).

Evaluating the data from Table 9 by means of the Arrhenius equation

$$
\ln \mathrm{k}_{\mathrm{a}}=\ln \mathrm{A}-\frac{\mathrm{E}_{\mathrm{A}}}{\mathrm{RT}}
$$

$\mathrm{A}=$ Arrhenius factor

$\mathrm{E}_{\mathrm{A}}=$ energy of activation in $\mathrm{kJ} / \mathrm{mol}$

$\mathrm{R}=$ gas constant

$\mathrm{T}=$ temperature in $\mathrm{K}$

where $\ln \mathrm{k}_{\mathrm{a}}$ is plotted against 1/RT (Fig. 9) results in an activation energy for the primary reaction of $47 \mathrm{~kJ} / \mathrm{mol}$.

With the aid of this value for the energy of activation and the following relationship derived from equation (2)

$$
\ln \mathrm{k}_{\mathrm{a}}\left(\mathrm{T}_{2}\right)=\ln \mathrm{k}_{\mathrm{a}}\left(\mathrm{T}_{1}\right)+\frac{\mathrm{E}_{\mathrm{A}}}{\mathrm{R}\left(\mathrm{T}_{1}-\mathrm{T}_{2}\right)}
$$

It is now possible to calculate the rate constants of the primary reaction for the technically interesting temperature range. These,
Table 10 Calculated rate constants $\left(k_{\mathrm{a}}\right)$ and half-lives $\left(\tau_{1 / 2}\right)$ for the primary reaction at high temeperatures.

\begin{tabular}{c|c|c|c}
\hline Temp. $\left({ }^{\circ} \mathrm{C}\right)$ & 120 & 140 & 160 \\
\hline $\mathrm{k}_{\mathrm{a}}\left(\mathrm{min}^{-1}\right)$ & 0.061 & 0.122 & 0.229 \\
\hline$\tau_{1 / 2}(\min )$ & 11.4 & 5.7 & 3 \\
\hline
\end{tabular}

together with the affiliated half life period are shown in Table. 10.

Secondary Reaction. - Three sequential reaction steps (secondary reactions) of the first order based on the path of the curve in Fig. 7 and on investigations with the model reaction (B, C, D) were formulated additionally to the equation for the primary reaction.

TESPT $\stackrel{k_{3}}{\rightarrow} \mathrm{Z} 1+2 \mathrm{EtOH}(\mathrm{A})$ Primary reaction
$\mathrm{Z} 1 \stackrel{\mathrm{k}_{\mathrm{b}}}{\rightarrow} \mathrm{Z} 2+\mathrm{EtOH}$
(B) Secondary reactions
$\mathrm{Z} 2 \stackrel{\mathrm{k}_{\mathrm{b}}}{\rightarrow} \mathrm{Z3}+\mathrm{EtOH}$
$\mathrm{Z} 3 \stackrel{\mathrm{k}_{\mathrm{b}}}{\rightarrow} \mathrm{P}+\mathrm{EtOH}$

$\mathrm{k}_{\mathrm{b}}=$ rate constant in minutes ${ }^{+1}$

$Z 1, Z 2, Z 3=$ intermediate products

$\mathrm{P}=$ final product of the reaction between silica and TESPT

The reaction model (A)-(D) as shown above corresponds to the following differential equations for the separate reaction rates.

$\frac{\mathrm{d}[\text { TESPT }]}{\mathrm{dt}}=\mathrm{k}_{\mathrm{a}}[\text { TESPT }]_{0}$

$\frac{\mathrm{d}[\mathrm{Z} 1\rceil}{\mathrm{dt}}=\mathrm{k}_{\mathrm{a}}(\mathrm{TESPT}]_{0}-\mathrm{k}_{\mathrm{b}}(\mathrm{Z} 1]$

$\frac{\mathrm{d}[Z 2]}{\mathrm{dt}}=\mathrm{k}_{\mathrm{b}}[Z 1]-\mathrm{k}_{\mathrm{b}}[Z 2]$

$\frac{\mathrm{d}[Z 3]}{\mathrm{dt}}=\mathrm{k}_{\mathrm{b}}[Z 2]-\mathrm{k}_{\mathrm{b}}[Z 3]$

$\frac{\mathrm{d}(\mathrm{P})}{\mathrm{dt}}=\mathrm{k}_{\mathrm{b}}\{\mathrm{Z} 3]$

$\frac{\mathrm{d}[\mathrm{EtOH}]}{\mathrm{dt}}=2 \mathrm{k}_{\mathrm{a}}[\mathrm{TESPT}]_{0}+[\mathrm{Z} 1]+\mathrm{k}_{\mathrm{b}}[\mathrm{Z} 2\rfloor+\mathrm{k}_{\mathrm{b}}$ [Z3]

$[Z 1\rceil,\lceil Z 2\rfloor,\lceil Z 3\rceil=$ concentrations of the intermediate products $Z 1, Z 2, Z 3$ in $\mathrm{mol} / \mathrm{kg}$

The paths of the reaction measured in the temperature range $120-160^{\circ} \mathrm{C}$ can be simulated using the model reaction (A)-(D) and the differential equations (4)-(9) which were 


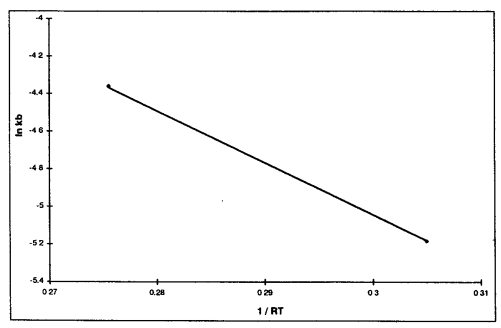

Fig. 10 Determination of the energy of activation for the secondary reaction

Table 11 Rate constants for primary reaction $\left(\mathrm{k}_{\mathrm{a}}\right)$ and the reacion steps of the secondary reaction $\left(\mathrm{k}_{\mathrm{b}}\right)$ at different temperatures.

\begin{tabular}{c|c|c|c}
\hline Temp. $\left({ }^{\circ} \mathrm{C}\right)$ & 120 & 140 & 160 \\
\hline $\mathrm{k}_{\mathrm{a}}\left(\mathrm{min}^{-1}\right)$ & 0.061 & 0.122 & 0.229 \\
\hline $\mathrm{k}_{\mathrm{b}}\left(\mathrm{min}^{-1}\right)$ & 0.005 & 0.008 & 0.012 \\
\hline
\end{tabular}

developed from it. The simulation was carried out by numerically integrating the differential equations (4)-(9). The rate constants for the primary reaction $\left(k_{\mathrm{a}}\right)$ which were determined from experimental data at lower temperatures by equation (3), were used for this purpose.

The rate constants $k_{b}$ for the secondary reaction are obtained by matching the simulated ethanol concentration profile to the experimental path of the ethalol concentration.

The rate constants for the secondary reaction found in this manner are shown in Table 11 and compared to those for the primary reaction.

It is seen that the primary reaction is about 20 times faster than the secondary reaction. Evaluating the data from Table 11 by means of the Arrhenius equation

$$
\ln \mathrm{k}_{\mathrm{a}}{ }^{\prime}=\ln \mathrm{A}-\frac{\mathrm{E}_{\mathrm{A}}{ }^{\prime}}{\mathrm{RT}}
$$

$\mathrm{A}=$ Arrhenius factor

$\mathrm{E}_{\mathrm{A}}{ }^{\prime}=$ energy of activation in $\mathrm{kJ} / \mathrm{mol}$

$\mathrm{R}=$ gas constant

$\mathrm{T}=$ temperature in $\mathrm{K}$

where $\ln \mathrm{k}_{\mathrm{a}}{ }^{\prime}$ is plotted against 1/RT (Fig. 10) results in an activation energy for the secon-

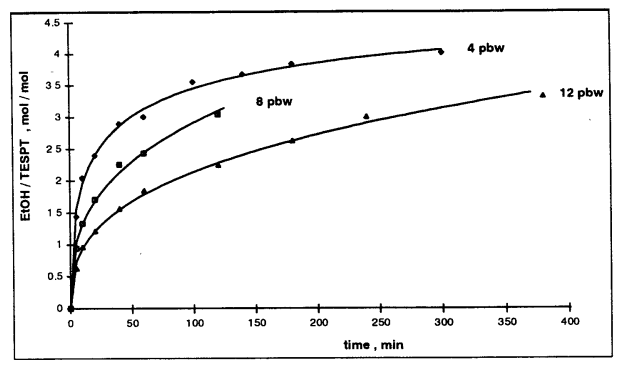

Fig. 11 Ethanol evolution with different TESPT concentrations at $140^{\circ} \mathrm{C}$

Table 12 Rate constants for the primary reaction $k_{a}$ at $50^{\circ} \mathrm{C}$ with various silane concentrations

\begin{tabular}{c|c|c|c}
\hline $\begin{array}{c}\text { Silane } \\
\text { concentration } \\
(\%)\end{array}$ & 4 & 8 & 12 \\
\hline $\mathrm{k}_{\mathrm{a}}\left(\mathrm{min}^{-1}\right)$ & 0.0051 & 0.0027 & 0.0014 \\
\hline
\end{tabular}

Table 13 Rate constants for the primary reaction $\left(k_{\mathrm{a}}\right)$ and the different steps of the secondary reaction $\left(\mathrm{k}_{\mathrm{b}}\right)$ at $140^{\circ} \mathrm{C}$ and various silane concentrations

\begin{tabular}{c|c|c|c}
\hline $\begin{array}{c}\text { Silane } \\
\text { concentration } \\
(\%)\end{array}$ & 4 & 8 & 12 \\
\hline $\mathrm{k}_{\mathrm{a}}\left(\mathrm{min}^{-1}\right)$ & 0.23 & 0.122 & 0.063 \\
\hline $\mathrm{k}_{\mathrm{b}}\left(\mathrm{min}^{-1}\right)$ & 0.02 & 0.008 & 0.004 \\
\hline
\end{tabular}

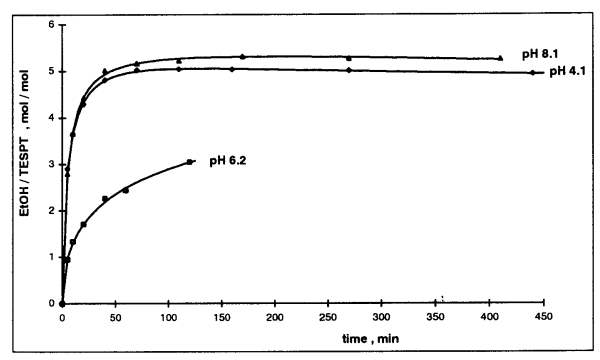

Fig. 12 Ethanol evolution dependance on $\mathrm{pH}$ values

dary reaction of $28 \mathrm{~kJ} / \mathrm{mol}$.

\section{INFLUENCE OF THE SILANE CONCENTRATION}

Figure 11 shows the evolution of ethanol at 
Table 14 Rate constants for the primary reaction $\left(\mathrm{k}_{\mathrm{a}}\right)$ and the reaction steps of the secondary reac tion $\left(\mathrm{k}_{\mathrm{b}}\right)$ at $140^{\circ} \mathrm{C}$ and various $\mathrm{pH}$ values

\begin{tabular}{c|c|c|c}
\hline $\mathrm{pH}$ & 4.1 & 6.2 & 8.1 \\
\hline $\mathrm{k}_{\mathrm{a}}\left(\mathrm{min}^{-1}\right)$ & 9.55 & 0.122 & 0.738 \\
\hline $\mathrm{k}_{\mathrm{b}}\left(\mathrm{min}^{-1}\right)$ & 0.17 & 0.008 & 0.18 \\
\hline
\end{tabular}

$140^{\circ} \mathrm{C}$ in relation to the silane concentration $(5$, 8 and 12 pbw TESPT). It is observed that ethanol is more quickly evolved at lower silane concentrations.

The rate constants for the primary reaction at $50^{\circ} \mathrm{C}$ in dependence on the silane concentration are shown in Table. 12

The rate constants for the primary and secondary reactions at $140^{\circ} \mathrm{C}$ are shown in Table. 13.

The rate constants for the 3 reaction steps of the secondary reaction follow the same path as those in the primary reaction and become smaller with increasing silane concentration.

\section{INFLUENCE OF SILICA PH VALUE}

TESPT ( $8 \mathrm{pbw}$ ) was reacted with silicas of different $\mathrm{pH}$ value at $140^{\circ} \mathrm{C}$ and ethanol evolved was measured (Fig. 12).

The reaction proceeds much faster when the $\mathrm{pH}$ value lies markedly in the acid or alkaline range than when it is almost neutral. The primary and secondary reaction rate constants obtained at $140^{\circ} \mathrm{C}$ are shown in Table. 14 .

The primary reaction and also the 3 reactions steps of the secondary reaction are catalysed both in the acidic and alkaline range, whereby the primary reaction in the acid range is overproportionally accelerated.

\section{INFLUENCE OF SILICA WATER CONTENT}

TESPT ( 8 pbw) was reacted with sillicas of different $\mathrm{H}_{2} \mathrm{O}$ contents $(2.5 ; 5.5$ and $8 \%)$ at $140^{\circ} \mathrm{C}$ and the amount of ethanol evolved was measured (Fig. 13).

The rate of ethanol evolution increased as

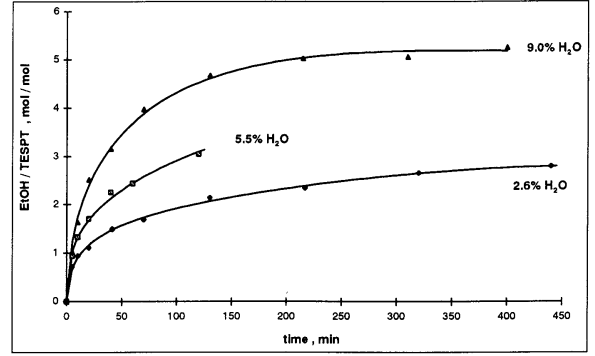

Fig. 13 Ethanol evolution related to the moisture content

Table 15 Rate constants at $140^{\circ} \mathrm{C}$ for the primary and secondary reaction

\begin{tabular}{c|c|c|c}
\hline $\begin{array}{c}\text { Moisture content } \\
2 \mathrm{~h} / 105^{\circ} \mathrm{C} \\
(\%)\end{array}$ & 2.6 & 5.5 & 9 \\
\hline $\mathrm{k}_{\mathrm{a}}\left(\mathrm{min}^{-1}\right)$ & 0.035 & 0.122 & 0.122 \\
\hline $\mathrm{k}_{\mathrm{b}}\left(\mathrm{min}^{-1}\right)$ & 0.002 & 0.008 & 0.04 \\
\hline
\end{tabular}

the $\mathrm{H}_{2} \mathrm{O}$ content rose (Table 15).

The rate of reaction of the primary reaction is independent of $\mathrm{H}_{2} \mathrm{O}$ content at over 5.5 weight $\% \mathrm{H}_{2} \mathrm{O}$. The rate of reaction decreases markedly when the $\mathrm{H}_{2} \mathrm{O}$ content is under $5.5 \%$. The secondary reaction on the other hand is accelerated by $\mathrm{H}_{2} \mathrm{O}$ over the whole test range.

\section{CONCLUSIONS}

The reaction of precipitated silicas with the organofunctional triethoxy silane (TESPT) was investigated. The influence of various parameters (silane concentration, $\mathrm{pH}$, moisture content) on the reaction type, degree of reaction and the reaction kinetics were considered. The results of the investigation can be summarized as follows :

- Modification with different silane concentrations yielded no significant differences in the efficiency of the reaction, i.e. formation of siloxane functions. However, the data obtained provide indications regarding a noticeably higher degree of hydrolysis of the silane at low concentrations and hence a greater amount of ethanol formed per mole 
of silane.

- It was observed that the use of acidic and alkaline silicas and a higher moisture content of the filler favor the reaction with the silane (greater efficiency of the reaction). Apparently, these two factors favor the hydrolysis of the triethoxysilyl group.

- The data obtained agree well with a horizontal reaction model in which a single siloxane bond is first formed with the silica surface (primary reaction), either directly or after (partial) hydrolysis of the silane. After having given off further ethanol, it is followed by condensation reactions between silanol groups of silane molecules which are already bound to the silica surface (secondary reaction).

The kinetic studies show a clear difference between the quick primary reaction and the slow secondary reaction. The energy of activation according to Arrhenius was determined for both reactions and was found to be much lower for the secondary reaction. Both reactions become quicker in the acidic and alkaline ranges respectively.

The primary reaction accelerates up to a particular $\mathrm{H}_{2} \mathrm{O}$ content after which the rate remains constant. The secondary reaction on the other hand keeps on accelerating with rising $\mathrm{H}_{2} \mathrm{O}$ content.

The results from the kinetic investigation conform closely to those from spectroscopic investigations.

(Presented at a meeting of the Rubber Division, American Chemical Society, Louisville, Kentucky, October 8-11, 1996)

\section{REFERENCES}

1) Wolff. S. Silanes in Tire Compounding after Ten Years-Review-Third Annual Meeting and Conference on Tire Science and Technology, The Tire Society, March 28-29, 1984, Akron, Ohio/USA

2 ) Agostini, G., Berg, J., Materne, Th. New Compound Technology. Oct. 1994, Akron, Ohio/USA

3 ) Wolff, S. The Influence of Fillers on Rolling Resistance, presented at the 129th Meeting of the Rubber Division American Chemical Society, New York, April 8-11, 1986

4) Wolft, S. The Role of Rubber-to-Silica Bonds in Reinforcement, presented at the First Franco-German Rubber Symposium, Nov. 14-16, 1985, Obernai/France

5 ) EP O 501227, US5.227.425

$6)$ Maciel, G. E., Sindorf, D. W. : J. Am. Chem. Soc. 102, $7606(1980)$

7 ) Engelhardt, G., Michel, D. : High-Resolution SolidState NMR of Silicates and Zeolites: John Wiley \& Sons: Chichester 1987

8 ) Gronski, W.: unpublished results

9) Sindorf, D. W., Maciel, G. E. : J. Am. Chem. Soc. 105, 3767 (1983)

10) Sindorf, D. W., Maciel, G. E.: J. Phys. Chem. 86, 5208(1982)

11) Liebau, E. "Structure Chemistry of Silicates", Springer Verlag 1985 